\title{
Detection of high level aminoglycoside resistance genes among clinical isolates of Enterococcus species
}

\author{
Manal Diab ${ }^{1}$ Dalia Salem¹, Ahmed El-Shenawy ${ }^{1}$, Amira El-Far ${ }^{1 *}$, Aya Abdelghany², Alaa Reda Awad ${ }^{3}$, \\ Inas El Defrawy ${ }^{1}$ and Mohamed Shemis ${ }^{2}$
}

\begin{abstract}
Background: Enterococci are intrinsically resistant to clinically achievable concentrations of aminoglycosides. However, high-level resistance to aminoglycosides (HLAR) is primarily due to the acquisition of genes encoding aminoglycoside-modifying enzymes (AMEs). Aminoglycosides along with cell wall inhibitors are given clinically for treating enterococcal infections. The current study was conducted to investigate the rate of HLAR and to determine aminoglycoside resistance encoding genes profile in enterococcal isolates from different clinical specimens.

Results: From 120 Enterococcus species, 50 (41.7\%) enterococcal isolates were proven to have HLAR, 78\% (39/50) have high-level gentamicin resistance (HLGR), and 74\% (37/50) were high-level streptomycin-resistant (HLSR). HLGR isolates carried aminoglycoside modifying gene aac (6')-le-aph (2')-la in 26/39 (66.7\%) of isolates, whereas 32/37 (86.5\%) of HLSR carried aph (3')-Illa gene and were observed in E. faecalis, E. faecium, E. gallinarum, and E.

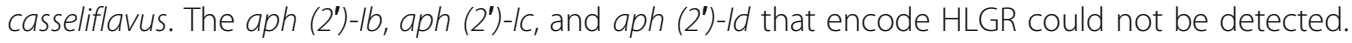

Conclusions: The high detection rate of HLAR among the studied Enterococcus species and the coexistence of HLGR and HLSR strains provide crucial insights to the necessity of routine testing for HLAR in the microbiology lab. The main AME genes among HLGR and HLSR enterococci were aac (6')-le-aph (2")-la and aph (3')-IIla, respectively.
\end{abstract}

Keywords: Enterococcus species, High-level aminoglycoside resistance, Aminoglycoside-modifying enzyme gene

\section{Background}

Enterococci have emerged as an important source of hospital-acquired infections, including those related to the surgical site, respiratory tract, urinary tract, skin and soft tissue infections, and bacteremia. Control and treatment of enterococcal infections are problematic due to their intrinsic resistance to various antimicrobials, their capabilities to develop new resistance and to survive in the external environment for a long time $[1,2]$.

Enterococci acquire resistance to a wider range of antimicrobial agents particularly, aminoglycosides, glycopeptides, and beta-lactams. This poses a therapeutic challenge to clinicians as they are left with very few treatment options $[3,4]$. A common regimen for the

\footnotetext{
* Correspondence: amiraelfar@hotmail.com

${ }^{1}$ Microbiology Department, Theodor Bilharz Research Institute (TBRI), Giza

12511, Egypt

Full list of author information is available at the end of the article
}

treatment of serious enterococcal infections is the synergistic combination of cell wall inhibitors as vancomycin with aminoglycosides [5].

Although enterococci are intrinsically resistant to low levels of aminoglycosides, high-level resistance to aminoglycosides (HLAR) is mediated by acquisition of genes encoding aminoglycoside-modifying enzymes (AME). High-level gentamicin resistance (HLGR) in enterococci is predominantly mediated by aac (6')-Ie-aph(2')-Ia gene, which encodes the bifunctional aminoglycoside modifying enzyme AAC (6')-APH (2'). The action of such enzyme in enterococci eliminates the synergistic activity of gentamicin when combined with a cell wall active agent, such as ampicillin or vancomycin. Other AME genes conferring gentamicin resistance such as aph (2')-Ib, aph (2')-Ic, and aph (2")-Id have been also detected in enterococci. Furthermore, highlevel streptomycin and kanamycin resistance in enterococci are mediated by aph (3')-IIIa [6]. 
To our knowledge, limited studies on AME genes profile were done in Egypt. The current study was conducted to investigate the rate of HLAR and to determine aminoglycoside resistance-encoding genes profile in enterococcal isolates from different clinical specimens.

\section{Methods}

\section{Bacterial isolates and species identification}

A prospective study was conducted from November 2016 to March 2018. A total number of 120 non-repetitive enterococcal isolates were collected from different clinical samples from outpatient clinic and hospitalized patients. The clinical specimens were initially cultured on MacConkey agar (HiMedia, India) and Cysteine-Lactose-Electrolyte-Deficient (CLED) media (Bio-Rad, USA). Isolates of enterococci were identified by Gram staining, colony morphology, catalase test, and growth on Bile Esculin agar (Oxoid, England). All isolates were identified to species level using Vitek2 automated system (bioMérieux, France).

\section{Detection of HLAR in enterococcal isolates}

Enterococcus species isolates were screened for HLAR by Kirby-Bauer disc diffusion method using streptomycin $(300 \mu \mathrm{g})$ and gentamicin $(120 \mu \mathrm{g})$ discs (Bio-Rad, France), and results were interpreted according to the Clinical and Laboratory Standards Institute [7]. Isolates that revealed HLAR by disc-diffusion method were further tested for determining the minimum inhibitory concentrations (MICs) of streptomycin and gentamicin using the E-test (bioMérieux Mercy, France). Overnight bacterial suspensions of test isolates were adjusted to 0.5 MacFarland turbidity and were plated on Muller Hinton agar (MHA) (HIMEDIA) plates and E-test strips (BioMerieux France) were applied. The plates were incubated at $35^{\circ} \mathrm{C}$ for $15-18 \mathrm{~h}$. Results were interpreted according to The European Committee on Antimicrobial Susceptibility Testing [8].

Bacterial isolates were stored at $-70^{\circ} \mathrm{C}$ in the form of glycerol stock until processed for DNA extraction and molecular analysis of AME [9].
Molecular analysis of aminoglycoside modifying genes by PCR assay

Genomic DNA was extracted from Enterococcus strains by cell lysis using a simple boiling technique [10]. The quality and quantity of DNA were assessed with NanoDrop 1000 (Thermo Scientific, USA). PCR assay for AME genes: aac (6')-Ie-aph (2")-Ia, aph (2")-Ib, aph $\left(2^{\prime \prime}\right)$-Ic, aph (2")-Id, and aph (3')-IIIa, was carried out using $4 \mu \mathrm{L}$ of bacterial DNA extract, $25 \mathrm{pmol}$ of each primer (Table 1), $200 \mathrm{mM}$ of each dNTP (Promega, Inc., USA), $10 \mathrm{mM} \mathrm{KCl} \mathrm{PCR} \mathrm{buffer,} 1.5 \mathrm{mM} \mathrm{MgCl}$, and $1.5 \mathrm{U}$ Taq polymerase (Gotaq Flexi DNA, M8305, Promega, Inc., USA). Amplification was carried out on a Bio-Rad thermal cycler using standard PCR protocol. The cycling conditions were as follows: $5 \mathrm{~min}$ of initial denaturation at $95^{\circ} \mathrm{C}$, followed by 35 cycles of denaturation at $95^{\circ} \mathrm{C}$ for $1 \mathrm{~min}$, annealing at $58^{\circ} \mathrm{C}$ for $1 \mathrm{~min}$ and strand extension at $72{ }^{\circ} \mathrm{C}$ for $1 \mathrm{~min}$ and a final extension for $10 \mathrm{~min}$ [11]. A negative control (lacking DNA) was included in each PCR assay. PCR products were analyzed on a $2 \%$ agarose gel stained with ethidium bromide. DNA amplicons were visualized using a gel documentation system (cleaver scientific, UK).

\section{Results}

A total of 120 Enterococcus species isolates were revealed from different clinical samples. The predominant species comprised E. faecalis 68 (56.7\%), E. faecium 36 (30\%), E. gallinarum 12 (10\%), and E. casseliflavus 4 (3.3\%). Among the studied 120 Enterococcus species isolates, 50 (41.7\%) were HLAR. The highest rate of isolation was from urine specimens $72 \%(36 / 50)$, followed by blood $14 \%(7 / 50)$, pus $6 \%(3 / 50)$, wound swabs $4 \%(2 / 50)$, and both of ascetic fluid and sputum revealed only 1 strain (1/50) for each of them representing $2 \%$.

The 50 HLAR isolates included 78\% (39/50) HLGR and $74 \%(37 / 50)$ HLSR isolates by disc-diffusion method. HLAR was confirmed in all 50 Enterococcus species isolates by E test and had MIC values of $>512 \mu \mathrm{g} / \mathrm{ml}$ and > $128 \mu \mathrm{g} / \mathrm{ml}$ for gentamycin and streptomycin respectively.

Table 1 Primer sequences for amplification of aminoglycoside resistance genes used in PCR assay

\begin{tabular}{|c|c|c|c|}
\hline Target genes & Primer sequences $\left(5^{\prime}-3^{\prime}\right)$ & Amplicon bp & References \\
\hline $\operatorname{aac}(')-l e-a p h\left(2^{\prime \prime}\right)-1 a$ & $\begin{array}{l}\text { 5'-CAGGAATTTATCGAAAATGGTAGAAAAG-3' } \\
\text { 5'-CACAATCGACTAAAGAGTACCAATC-3' }\end{array}$ & 369 & {$[11]$} \\
\hline$a p h\left(2^{\prime \prime}\right)-1 b$ & $\begin{array}{l}\text { 5'-CTTGGACGCTGAGATATATGAGCAC-3' } \\
\text { 5'-GTTTGTAGCAATTCAGAAACACCCTT-3' }\end{array}$ & 867 & \\
\hline $\operatorname{aph}\left(2^{\prime \prime}\right)-1 c$ & $\begin{array}{l}\text { 5'-CCACAATGATAATGACTCAGTTCCC-3' } \\
\text { 5'-CCACAGCTTCCGATAGCAAGAG-3' }\end{array}$ & 444 & \\
\hline $\operatorname{aph}\left(2^{\prime \prime}\right)-I d$ & $\begin{array}{l}\text { 5'-GTGGTIITACAGGAATGCCATC-3' } \\
\text { 5'-CCCTCTTCATACCAATCCATATAACC-3' }\end{array}$ & 641 & \\
\hline$a p h\left(3^{\prime \prime}\right)-I I I a$ & $\begin{array}{l}\text { 5' -GGCTAAAATGAGAATATCACCGG-3' } \\
\text { 5'-CTITAAAAAATCATACAGCTCGCG-3' }\end{array}$ & 523 & \\
\hline
\end{tabular}


HLAR was predominant in E. faecalis 60\% (30/50) followed by E.faecium 30\% (15/50), E. gallinarum 8\% (4/ $50)$, and E. casseliflavus $2 \%(1 / 50)$ by Vitek 2 compact system. The species distribution and specimen source of HLAR Enterococcus strains were listed in Table 2.

Detection of AME encoding genes was performed for the 50 HLAR Enterococcus species isolates and showed that 39 (78\%) were HLGR of which $26 / 39$ (66.7\%) of the isolates carried the aac (6')-Ie-aph (2")-Ia gene (Table 3, Fig. 1), while from the HLSR 37(74\%) Enterococcus species strains, 32/37 (86.5\%) carried aph (3')-IIIa gene (Table 3, Fig. 2). Aminoglycoside resistance genes as aph (2")-Ib, aph (2')-Ic, and aph (2')-Id that encode HLGR could not be detected among the studied isolates.

E. faecalis and E. faecium were the predominant Enterococcus species isolates of the present study. They were found to carry the bifunctional enzyme encoding gene aac (6')-Ie-aph (2")-Ia in 17/30 (56.7\%) and 8/15 (53.3\%) strains respectively and aph (3')-IIIa gene in 18/ $30(60 \%)$ and $11 / 15$ (73.3\%) strains respectively (Table 3).

The coexistence of aac (6')-Ie-aph (2")-Ia and aph (3')-IIIa genes were revealed in E. faecalis, E. faecium, and $E$.casseliflavus strains. The two $E$. gallinarum strains were found to carry aph (3')-IIIa gene only (Table 4).

\section{Discussion}

Enterococci have long been considered as one of the most common causes of nosocomial infections. The rise of drug-resistant strains presents a serious problem to control in enterococcal infections. Several resistant Enterococcus species have been reported, including $E$. faecalis, E. faecium E. avium, E. durans, E. gallinarum, E. casseliflavus, E. raffinosus, E. mundtii, E. malodoratus, and E. hirae [12]. As previously found in Egypt [5, 13], $E$. faecalis and E. faecium are the predominant strains revealed in all clinical specimens in the present study.

Aminoglycosides are considered efficient in treating serious infections caused by both Gram-positive and

Table 2 Distribution of HLAR Enterococcus species from various clinical specimens

\begin{tabular}{llllll}
\hline Clinical & \multicolumn{5}{l}{ Distribution of Enterococcus species $(n=50)$} \\
\cline { 2 - 6 } & E. faecalis & E. faecium & E. gallinarum & E. casseliflavus & Total \\
\hline Urine & 19 & 13 & 3 & 1 & 36 \\
Blood & 7 & 0 & 0 & 0 & 7 \\
Wound & 2 & 0 & 0 & 0 & 2 \\
Ascitic fluid & 0 & 0 & 1 & 0 & 1 \\
Pus & 2 & 1 & 0 & 0 & 3 \\
Sputum & 0 & 1 & 0 & 0 & 1 \\
Total & 30 & 15 & 4 & 1 & 50
\end{tabular}

Data are presented as numbers $(N)$
Table 3 Distribution of aminoglycoside modifying enzymeencoding genes among Enterococcus species with high-level aminoglycoside resistance

\begin{tabular}{|c|c|c|c|c|c|}
\hline \multirow{2}{*}{$\begin{array}{l}\text { HLAR MIC and } \\
\text { detection of } \\
\text { genes by PCR }\end{array}$} & \multicolumn{5}{|c|}{ Distribution of HLAR in Enterococcus spp. $(N=50)$} \\
\hline & $\begin{array}{l}\text { E. faecalis } \\
\text { (30) }\end{array}$ & $\begin{array}{l}\text { E. faecium } \\
\text { (15) }\end{array}$ & $\begin{array}{l}\text { E. } \\
\text { gallinarum } \\
\text { (4) }\end{array}$ & $\begin{array}{l}\text { E. } \\
\text { casseliflavus } \\
\text { (1) }\end{array}$ & $\begin{array}{l}\text { Total } \\
(N)\end{array}$ \\
\hline HLGR (MIC) & 21 & 15 & 2 & 1 & 39 \\
\hline \multicolumn{6}{|c|}{ HLGR (gene detection) } \\
\hline $\begin{array}{l}\operatorname{aac}\left(6^{\prime}\right)-1 e- \\
\operatorname{aph}\left(2^{\prime \prime}\right)-1 a\end{array}$ & 17 & 8 & 0 & 1 & 26 \\
\hline$a p h\left(2^{\prime \prime}\right)-1 b$ & 0 & 0 & 0 & 0 & 0 \\
\hline $\operatorname{aph}\left(2^{\prime \prime}\right)-1 c$ & 0 & 0 & 0 & 0 & 0 \\
\hline $\operatorname{aph}\left(2^{\prime \prime}\right)-I d$ & 0 & 0 & 0 & 0 & 0 \\
\hline HLSR (MIC) & 23 & 10 & 3 & 1 & 37 \\
\hline \multicolumn{6}{|c|}{ HLSR (gene detection) } \\
\hline$a p h\left(3^{\prime}\right)-111 a$ & 18 & 11 & 2 & 1 & 32 \\
\hline
\end{tabular}

- Data are presented as numbers $(N)$

HLAR high-level aminoglycoside resistance, HLGR high-level gentamycin resistance, HLSR high-level streptomycin resistance

Gram-negative organisms. However, the acquisition of extrinsic resistance to high-level aminoglycoside antibiotics in enterococci renders these strains a serious challenge in clinical settings [14].

Distribution of HLAR in enterococcal isolates varied in different reports in the world. The current study results $(41.7 \%)$ were comparable to those obtained by ElGhazawy et al. [5] (35.3\%) that studied the prevalence of HLAR in 133 enterococcal strains obtained from different clinical samples at Alexandria Main University Hospital, Egypt. However, higher rates of HLAR enterococci (72\%) were obtained by Padmasini et al. [11] in India. Another study by El Mahdy et al. [15] at Mansoura University Hospitals in Egypt showed also higher HLAR results $(66.3 \%)$ in 80 enterococcal isolates recovered from urine samples. The present study revealed a high prevalence of HLSR strains (74\%), although the clinical use of streptomycin for infections caused by enterococci has long been restricted due to intrinsic low-level resistance of the organism [11].

Previous studies by Padmasini et al. [11], Bhatt et al. [16], and Niu et al. [17] have reported that HLGR $(42.7 \%$, 65\%, and $42.7 \%$ ) was more common than HLSR $(29.8 \%, 45 \%$, and $27.4 \%)$ in all species of isolated enterococci respectively. On the contrary, there was nearly no difference between the prevalence rates of HLGR and HLSR among our studied Enterococcus species isolates. Similar finding was found in Turkey by Kurtgoz et al. [18].

HLAR was found to be more common in E. faecalis and E. faecium [19], on the other hand, Abamecha et al. [20] and Bhatt et al. [16] reported that HLAR was a common problem among E. faecium isolates only. A 


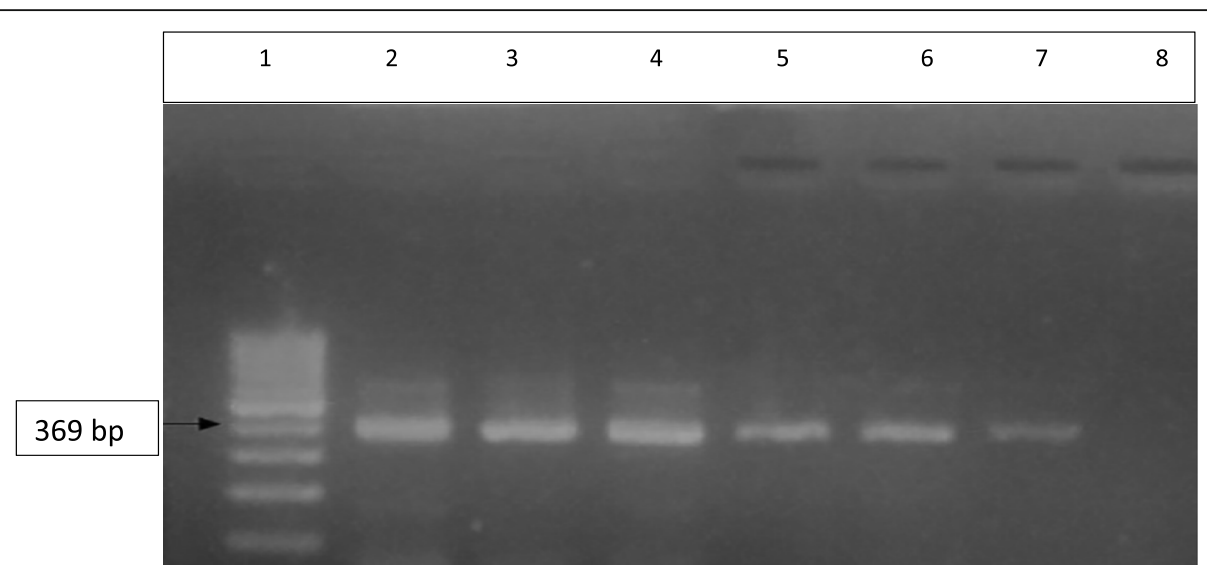

Fig. 1 Agarose gel electrophoresis of amplified product AME gene generated by PCR assay. Lane 1: molecular weight marker (ladder 100 bp); lane (2-7): aac (6')-le-aph(2")-la positive (369 bp). Lane 8: negative control

surveillance study that was conducted in 20 European countries had reported $32 \%$ and $22 \%$ HLGR and $41 \%$ and 49\% HLSR among HLAR E. faecalis and E. faecium, respectively [19]. In the current study, HLGR is $70 \%$ and $100 \%$, while HLSR is $76 \%$ and $67 \%$ among E. faecalis and $E$. faecium respectively. This emphasizes susceptibility differences within different enterococcal species.

In accordance with previous studies [5, 11, 17], the aac (6')-Ie-aph (2')-Ia gene (66.7\%) and aph (3')-IIIa $(86.5 \%)$ were identified as the most common AME genes among HLGR and HLSR strains, respectively. Nevertheless, the prevalence of the previous two genes was variable among these former studies. Padmasini et al. [11] stated that the aac (6')-Ie-aph (2')Ia was found in $68.4 \%$ of their HLAR enterococcal isolates which is comparable to our results, while 77.4\% carried aph (3')-IIIa gene. Niu et al. [17] and El Ghazawy et al. [5] revealed also higher rates of $a a c$ (6')-Ie-aph (2")-Ia gene being $89.3 \%$ and $95.7 \%$, respectively, which reflects their finding of higher pervasiveness of HLGR in their isolates.
It is noteworthy that the newer aminoglycoside modifying genes aph (2')-Ib, aph (2')-Ic, and aph (2')-Id that encode HLGR were not detected among the studied strains. This was in agreement with Padmasini et al. [11]. In contrast to our results, aph (2')-Ic gene was detected by El-Ghazawi et al. [5].

Both aac (6')-Ie-aph (2")-Ia and aph (3')-IIIa genes co-existed in isolated E. faecalis, E. faecium, and E. casseliflavus strains, which was in accordance with results obtained by Padmasini et al. [11] and El Mahdy et al. [15]. However, 9 out of the 50 of HLAR enterococcal strains did not carry any of the formerly tested genes. This may be due to the expression of genes other than genes analyzed in this study.

\section{Conclusion}

In conclusion, the high detection rate of HLAR among the studied Enterococcus species and the coexistence of HLGR and HLSR strains provide crucial insights into the necessity of HLAR testing as a routine microbiology procedure. The main AME genes among HLGR and

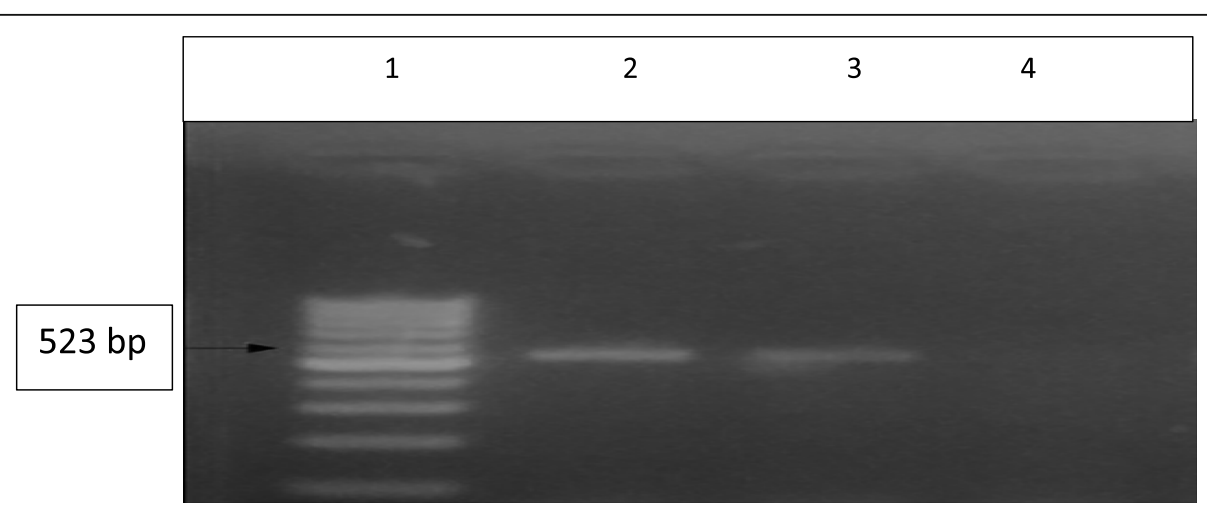

Fig. 2 Agarose gel electrophoresis of amplified product AME gene generated by PCR assay. Lane 1: molecular weight marker (ladder 100 bp); lanes (2 and 3): aph (3')-IIla positive (523 bp); lane (4): negative control 
Table 4 Aminoglycoside modifying enzyme-encoding genes profile among the 50 high-level aminoglycoside resistance Enterococcus species strains

\begin{tabular}{|c|c|c|c|c|}
\hline \multirow[t]{2}{*}{ Enterococcus species } & \multicolumn{4}{|c|}{ Aminoglycoside modifying enzyme-encoding genes profile } \\
\hline & $\begin{array}{l}\text { aac(6')-le-aph }\left(2^{\prime \prime}\right)-1 a+ \\
\text { ve }\end{array}$ & $\begin{array}{l}a p h\left(3^{\prime}\right)-I I I a+ \\
\text { ve }\end{array}$ & $\begin{array}{l}\text { aac( }\left(6^{\prime}\right)-l e-a p h\left(2^{\prime \prime}\right)-l a+\text { ve and } a p h\left(3^{\prime}\right)-1 / 1 a+ \\
\text { ve }\end{array}$ & $\begin{array}{l}\left.\text { aac( } 6^{\prime}\right) \text {-le-aph(2")-la ve and } a p h\left(3^{\prime}\right) \text { - IIIa- } \\
\text { ve }\end{array}$ \\
\hline E. faecalis $(N=30)$ & 7 & 8 & 10 & 5 \\
\hline E. faecium $(N=15)$ & 2 & 5 & 6 & 2 \\
\hline E. gallinarum $(N=4)$ & 0 & 2 & 0 & 2 \\
\hline $\begin{array}{l}\text { E. casseliflavus }(N= \\
\text { 1) }\end{array}$ & 0 & 0 & 1 & 0 \\
\hline
\end{tabular}

Data are presented as numbers $(N)$

HLSR enterococci were (6')-Ie-aph (2")-Ia and aph (3')IIIa, respectively. The limited AME-encoding genes among the studied HLAR Enterococcus species highlight the restricted gene distribution and transfer of resistant genes within a geographical region. The implementation of an efficient infection control program and regular surveillance of antimicrobial resistance of enterococci is essential in order to establish a rational antibiotic policy for the better management of enterococcal infections.

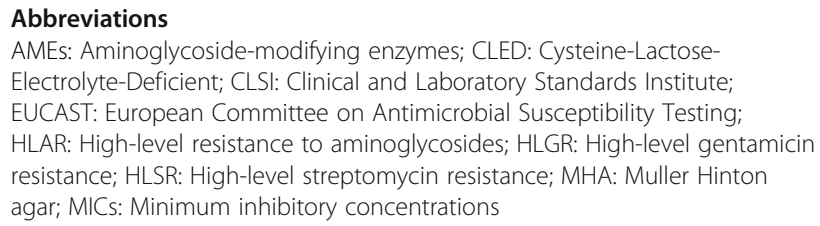

\section{Acknowledgements}

We would like to thank assistant lecturer Pakinam Hamzawi, Medical Microbiology Lab, TBRI, for her valuable assistance while doing the phenotypic identification of HLAR isolates and specialist Ayman Sallam, Biochemistry and Molecular Biology Lab, TBRI, for his kind assistance during the carrying out the PCR assay.

\section{Authors' contributions}

MD was responsible for the idea and concept of the research and revised the whole manuscript. DS analyzed, interpreted the data, and revised the manuscript. AE-S performed the microbiological identification and interpreted the results and was a contributor in writing the manuscript. AEF analyzed, interpreted the data and was a major contributor in writing and revising the manuscript. AA performed the molecular detection. ARA and IED revised the manuscript. MS performed the molecular detection and revised the manuscript. All authors read and approved the final manuscript.

\section{Funding}

Not applicable.

\section{Availability of data and materials}

Data and material are available with the corresponding author upon reasonable request.

\section{Ethics approval and consent to participate}

All specimens included in the study were archived, and codes were used instead of patient names. The protocol of the study was approved by TBRI institutional review board under Federal Wide Assurance (FWA00010609) and the work has been carried out in accordance with the Code of Ethics of the World Medical Association (Declaration of Helsinki) for Experiments in Humans and its later amendments (GCP guidelines) or comparable ethical standards.

\section{Consent for publication}

Not applicable as the specimens were coded and no patient data was used.

\section{Competing interests}

The authors declare that they have no competing interests.

\section{Author details}

${ }^{1}$ Microbiology Department, Theodor Bilharz Research Institute (TBRI), Giza 12511, Egypt. ${ }^{2}$ Biochemistry and Molecular Biology Department, Theodor Bilharz Research Institute (TBRI), Giza, Egypt. ${ }^{3}$ Medical Microbiology and Immunology Department, Faculty of Medicine, Cairo University, Cairo, Egypt.

Received: 1 July 2019 Accepted: 9 October 2019

Published online: 27 November 2019

\section{References}

1. Murray BE (1990) The life and times of the enterococcus. Clin Microbiol Rev 3:46-65

2. Baldir G, Engin DO, Küçükercan M, Inan A, Akçay S, Özyürek S et al (2013) High-level resistance to aminoglycoside, vancomycin, and linezolid in Enterococci strains. J Microbiol Infect Dis 3(3):100-103

3. Papaparaskevas J, Vatoupoulos A, Tassios PT, Tassios A, Avalmani N, Legakis NJ, Kalapothaki $V$ (2000) Diversity among high -level aminoglycoside resistant enterococci. J Antimicrob Chemo 45:277-283

4. Bhatt P, Shete V, Sahni AK, Grover N, Chaudhari CN, Dudhat VL et al (2014) Prevalence of high-level aminoglycoside resistance in enterococci at a tertiary care centre. Int J Recent Sci Res 5(8):1515-1517

5. El-Ghazawy I, Okasha H, Mazloum S (2016) A study of high level aminoglycoside resistant enterococci. Afr J Microbiol Res 10(16):572-577

6. Shete V, Grover N, Kumar M (2017) Analysis of aminoglycoside modifying enzyme genes responsible for high-level aminoglycoside resistance among Enterococcal isolates. J Pathog 2017;(Article ID 3256952):1-5

7. CLSI (2017) Performance Standards for Antimicrobial Susceptibilty Testing, 27th ed. CLSI supplement M100 Wayne,PA: Clinical and LaboratoryStandards Institute.

8. European Committee on Antimicrobial Susceptibility Testing. 2016 Breakpoint tables for interpretation of MICs and zone diameters, version 6.0

9. Sambrook J, Fritsch EF, Maniatis T (1989) Molecular cloning: a laboratory manual (Glycerol shock), vol 16, 2nd edn. Cold Spring Harbor Laboratory Press, Cold Spring Harbor, pp 32-35

10. Englen, Kelley LC (2008) A Rapid DNA isolation procedure for the identification of Campylobacter jejuni by the polymerase chain reaction. Appl Microbiol 31:421-426

11. Padmasini E, Padmaraj R, Ramesh S (2014) High level aminoglycoside resistance and distribution of aminoglycoside resistant genes among clinical isolates of Enterococcus species in Chennai, India. Sci World J 4:1-5

12. Tsiodras S, Gold HS, Coakley EP, Wennersten C, Moellering RC Jr, Eliopoulos GM (2000) Diversity of domain V of 23srRNA gene sequence in different Enterococcus species. J Clin Microbiol 38:3991-3993

13. Diab M, Fam N, El-Baz A (2000) A study on uropathogenic Enterococcus species. EJMM 9(4):745-751

14. Krause K, Serio A, Connolly L (2016) Aminoglycosides: an overview. Cold Spring Harb Perspect Med 6(6):a027029

15. El-Mahdy R, Mostafa A, El-Kannishy G (2018) High level aminoglycoside resistant enterococci in hospital-acquired urinary tract infections in Mansoura, Egypt. GERMS 8(4):186-190

16. Bhatt MP, Patel A, Sahni B, Praharaj SC, Grover CN, Chaudhari CN et al (2015) Emergence of multidrug resistant enterococci at a tertiary care Centre. Med J Armed Forces India 71(2):139-144 
17. Niu H, Yu H, Hu T, Tian G, Zhang L, Guo X et al (2016) The prevalence of aminoglycoside- modifying enzyme and virulence genes among enterococci with high-level aminoglycosides resistance in Inner Mongolia, China. Braz J Microbiol 47:691-696

18. Kurtgoz SO, Ozer B, Inci M, Duran N, Yula E (2016) Vancomycin and high-level aminoglycoside resistance in Enterococcus species. Microbiol Res 7:6441

19. Schmitz EJ, Verhoef J, Fluit AC (1999) Prevalence of aminoglycoside resistance in 20 European University hospitals participating in the European SENTRY antimicrobial surveillance programme. Eur J Clin Microbiol Infec Dis 18(6):414-421

20. Abamecha A, Wondafrash B, Abdissa A (2015) Antimicrobial resistance profile of Enterococcus species isolated from intestinal tracts of hospitalized patients in Jimma, Ethiopia. BMC Res Notes 8:213

\section{Publisher's Note}

Springer Nature remains neutral with regard to jurisdictional claims in published maps and institutional affiliations.

\section{Submit your manuscript to a SpringerOpen ${ }^{\circ}$ journal and benefit from:}

- Convenient online submission

- Rigorous peer review

- Open access: articles freely available online

- High visibility within the field

- Retaining the copyright to your article

Submit your next manuscript at $\boldsymbol{\wedge}$ springeropen.com 